Arhe XVIII, 36/2021

UDK $316.75: 519.76$

378.014 .15

DOI https://doi.org/10.19090/arhe.2021.36.353-383

Originalni naučni rad

Original Scientific Article

IGOR ŠEVO ${ }^{1}$

Univerzitet u Banjoj Luci, Elektrotehnički fakultet, BiH

\title{
DESTRUKTIVNI UTICAJ POSTHUMANISTIČKE SEMIOTIČKE IDEOLOGIJE NA AKADEMIJU KAO ARHETIPNI ENTITET
}

Sažetak: Aspekti ljudskog ponašanja pripisivani savremenom dobu ostaju suštinski nepromijenjeni prethodnih nekoliko stotina hiljada godina, ali savremena globalno dostupna tehnologija danas obezbjeđuje platformu za stvaranje novih selekcionih pritisaka na ljudsku vrstu, na ovaj način omogućavajući izmjenu ne samo genetičkog opisa jedinke nazvane čovjek, već i njenog fenomenskog iskustva. Globalno dostupna tehnologija omogućava amplifikaciju i propagaciju posthumanističke ideologije kroz implicitne semiotičke mehanizme zaobilazeći svjesnu percepciju i tako indirektno prijeteći izmjenom čovjeka i njegove svijesti na fenomenskom nivou. Na primjeru akademskog ideala, ovdje izlažem analitički argument za postojanje ideološke prijetnje dijeljenom fenomenskom iskustvu, pod premisom etičke i ontološke relevantnosti tog iskustva.

Ključne riječi: semiotička ideologija, kolektivno nesvjesno, posthumanizam, informacioni hazardi, akademija

\section{UVOD I MOTIVACIJA}

Evolucija živih organizama se tradicionalno smatra dugotrajnim procesom, pogotovo kada se govori o noogenezi (Chardin, 1955) i neophodnim bihevioralnim promjenama za manifestaciju promjena $\mathrm{u}$ noosferi (Alexey, 2005), ali razvoj i upotreba tehnika sekvenciranja gena „naredne generacije“ (Behjati \& Tarpey, 2013) ukazuje na to da se

\footnotetext{
${ }^{1}$ E-mail adresa autora: igor.sevo@etf.unibl.org
} 
značajne bihevioralne promjene mogu ispoljiti čak i unutar nekoliko generacija (Trut, Oskina, \& Kharlamova, 2009), te da promjene u ponašanju po hronološki ofsetovanoj povratnoj sprezi utiču na morfološke promjene unutar vrste, izlažući organizme novim selekcionim pritiscima (Lister, 2013).

Adaptacije na nivou genoma, iz perspektive savremene evolucijske biologije, rezultat su gotovo isključivo selekcionog pritiska, odnosno prirodne selekcije (Williams, 2018). S druge strane, kao posljedica socijalizacije ljudi kao vrste, pojavljuju se novi vidovi selekcionih mehanizama, kao što su rodbinska selekcija (Hamilton, 1964) i grupna selekcija (Abbot, Abe, Alcock, Alizon, \& al., 2011), obezbjeđujući platformu za razvoj altruističkog ponašanja (Kurzban, Burton-Chellew, \& West, 2015). Na ovaj način, biološka evolucija ljudske vrste, kao vrste specifične po svom kapacitetu za kompleksne socijalne interakcije, tekla je u povratnoj sprezi sa evolucijom kulture (Richerson, 2006) (Laland, 2008).

Za razliku od modernog čovjeka, čiji mozak čini oko stotinu milijardi neurona, jedna od najranijih Homo vrsta, Homo habilis, koja je živjela prije više od 1.4 miliona godina, brojala je četrdeset milijardi neurona, a procjene za Homo neanderthalensis kreću se oko 85 milijardi neurona (Herculano-Houzel, Brain Evolution, 2012). Očigledan je trend linearnog skaliranja nervnog kapaciteta kod primata (Herculano-Houzel, The Human Brain in Numbers: A Linearly Scaled-up Primate Brain, 2009) i slojevita organizacija nervnih struktura, pri čemu se noviji slojevi javljaju kasnije u procesu evolucije i gotovo isključivo kod sisara (Lui, Hansen, \& Kriegstein, 2011) (Rakic, 2009) (Courten-Myers, 1999). Uzevši u obzir da je sam nervni sistem star preko 500 miliona godina (Tortora, 2008), te da je funkcija i onih primitivnijih moždanih struktura i dalje predmet aktivnog istraživanja (Bower, 2003), razumno je pretpostaviti da dio ovih struktura sadrži potencijalno nepoznate mehanizme koji djeluju na ono što bi tipično bilo okarakterisano kao svjesno ponašanje. Štaviše, potraga za takozvanim lokusom svijesti, odnosno neuronskim korelatom fenomenskog iskustva svijesti, tipično rezultuje modelima koji semantički povezuju određene specifične regione mozga (McFadden, 2020) (Demertzi, Tagliazucchi, Dehaene, \& 
al., 2019) (Siclari, Baird, Perogamvros, \& al., 2017) (Casali, Gosseries, Rosanova, \& al., 2013) (Monti, Vanhaudenhuyse, Coleman, \& al., 2010) (Owen, Coleman, Boly, \& al., 2006) (Fischer, Boes, Demertzi, \& al., 2016), isključujući druge, što sugeriše postojanje nervnih mehanizama čija se aktivnost ne manifestuje očigledno u fenomenskom iskustvu svijesti, odnosno na nivou onoga što bi psihološki bilo denominovano kao ego (Jung C. , 1959).

Očigledno je da ljudski nervni sistem sadrži izuzetno stare mehanizme koji omogućavaju ispoljavanje obrazaca ponašanja specifičnih precima, pa se može zaključiti da on koduje sva ona a priori znanja koja savremeni čovjek dijeli sa svojim precima (Walters, 1994). Iz jungovske perspektive, koncepti naslijeđeni od predaka i obrasci ponašanja prisutni u različitim kulturama i civilizacijama kao rezultat dijeljene evolucijske istorije egzistiraju unutar psihe kao entiteti sa kojima ego interaguje i koje ego može da utjelovi (Jung C. G., 1968) (Samuels, 1986). Iako su ovi entiteti, tipično zvani arhetipovima, kategorije relativno specifične za oblast psihoanalize, neizbježan je čvrsti aksiom cijelog polja psihoanalize: najvažniji mitološki motivi su zajednički za sva vremena i rase (Wilber, 1996, p. 57). Prema Jungu, jedan od najznačajnijih ovakvih psiholoških entiteta je takozvani senex odnosno Mudri Starac (Jung C. G., The Collected Works of C.G. Jung, 2014) (Jung C. G., The Archetypes and the Collective Unconscious, 1991) (Jung C. G., Four Archetypes, 2014), utjelovljen u psihi kao onaj čije riječi pomažu heroju kroz iskušenja $i$ užase neobične avanture (Campbell, 1973, str. 8) i koji se mitološki pojavljuje kao figura koja posjeduje autoritet i mistično znanje, često kao učenjak ili profesor. Prema riječima Žozefa Kempbela, doktor je savremeni majstor mističnog domena, onaj koji poznaje sve tajne načine i riječi potentne (Campbell, 1973, str. 8). Kao enantiodromijsku (Jung C. G., Psychological Types, 1976) antitežnju arhetipu Mudrog Starca, Jung ustanovljuje i puera eternus, arhetip vječnog djeteta, onoga ko je sve in potentia, i ko ne odabira put, već čeka da „njegovo vrijeme“ dođe, te da se njegova sudbina sama obistini, bez djelovanja ka ličnoj promjeni ili usavršavanju, što se, iz psihoanalitičke perspektive, manifestuje kao inflacija percepcije lične važnosti (Edinger, 1992). 
Razumno je pretpostaviti da mnogi od ovih primordijalnih entiteta postoje u ljudskoj psihi od začetka ljudske vrste, dok neki sežu i dalje u prošlost do predaka ljudske vrste, u onoj mjeri u kojoj su im slični nervni sistemi i odgovarajuće nervne strukture. Ovdje se nameću suštinska filosofska, kako ontološka tako i etička, pitanja: da li je zaštita i očuvanje ovih entiteta neophodan uslov za opstanak ljudske vrste $u$ obliku u kom ona trenutno postoji i da li smrt bilo kog od arhetipova koji postoje u domenu kolektivnog nesvjesnog, bila ona simboličkog ili drugog modaliteta, istovremeno implicira i izumiranje čovjeka kao vrste? Kako se čovječanstvu, uz podršku tehnologije, ukazuje mogućnost da dovodi u pitanje mehanizme koji pokreću individualnu i kolektivnu svijest (Harari, 2017), i kako se ukazuje prilika da ono odstrani, iz dubine sebe, neki od primordijalnih entiteta, arhetip, drevno božanstvo još uvijek u cjelini nesagledano, postaje izvjesno da će Ničeove riječi poprimiti novo značenje (Nietzsche, 1882, str. 153).

Gdje je Bog? ... Reći ću vam. Ubili smo ga - ja i ti! Svi smo ga mi ubili! Ali kako smo to uradili? Kako smo ispili more? Ko nam je dao sunđer da izbrišemo cijeli obzor? Šta smo uradili kada smo odvojili ovu zemlju od njenog sunca? Gdje se sada kreće? Gdje se mi krécemo? Odmičemo li se od svih sunca? Zar se padamo neprestano? Unatrag, postrance, prema naprijed, u svim smjerovima? Postoje li još gore ili dole? Zar se nismo izgubili kao u beskonačnom ništavilu? Zar ne osjećamo dah praznog svemira? Zar nije postao hladniji? Zar se noć neprestano ne obrušava na nas? Zar ne treba paliti svjetiljke ujutro? Zar ne čujemo ništa drugo osim zvukova grobara koji pokapaju Boga? Zar ne osjećamo ništa osim božanskog raspadanja? - Bogovi se takođe raspadaju! Bog je mrtav!

Začeci religije (Wunn, 2000), kao i začeci simboličke umjetnosti kao prenosnika ideja (Tylén, Fusaroli, Rojo, \& al., 2020), sežu dalje u prošlost od najstarijeg pisma, što, zajedno sa novijim arheološkim saznanjima (Wurz, 2012), sugeriše da se obrasci ponašanja koji bi tipično bili pridruženi savremenom dobu, kao što su, između ostalog, spontana simbolička komunikacija (Henshilwood \& Marean, 2003) i sposobnost planiranja i rješavanja problema (Wynn \& Coolidge, 2011), pojavljuju unazad i do 200 hiljada godina. Prema tome, zanemarujući specifične adaptacije, može da se izvede zaključak da je savremeni 
čovjek, na genetičkom nivou (Schaffner \& Sabeti, 2008), kao i na dijeljenom simboličkom nivou, dovoljno blizak svojim precima koji su živjeli na planeti stotine hiljada godina u prošlosti da se može smatrati da se radi o suštinski istom biću.

Pored očiglednih psihoanalitičkih implikacija za isto (Jung C. G., The Collected Works of C.G. Jung, 2014), relativno novi pomaci u filosofiji i nauci uma (Hoffman, 2008) ukazuju na to da fenomenske reprezentacije stvarnosti prezentovane egu ne moraju nužno oslikavati stvarnost, te su gotovo uvijek interpretirane na simboličkom nivou, pa se, na osnovu ove opservacije, uzevši u obzir da arhetipovi ne predstavljaju nužno samo simboličke entitete, već i obrasce ponašanja, konceptualizacija osnovnih arhetipova može proširiti i na relevantne implicitne kategorije. Konkretnije, kada se govori o arhetipu Mudrog Starca, implicitna je relacija autoriteta po znanju ili vještini prema arhetipnom učeniku. Pored brojnih primjera iz književnosti, gdje se senex tipično predstavlja, u različitim oblicima, kao benevolentni mudrac, mentor ili profesor (Frye, 1957), jedno od najpoznatijih istorijskih svjedočanstava o fizičkom utjelovljenju ovakvog oblika arhetipnog ponašanja, kao i veze mentor-učenik, jeste Platon i njegova Akademija, formirana četiri vijeka prije nove ere (Lindberg, 2008) za svrhu rješavanja naučnih i filosofskih problema (Dancy, 1991). Naravno, ideja organizovanog školovanja i mentorskog obrazovanja datira vijekove prije Platona (Rury \& Tamura, 2019), ali neizbježna je istorijska činjenica da je institucija akademije baš po ovome dobila ime i da je idealizacija ovakve ideje akademije simbolički izronila, pored književnih, kroz djela kao što je Rafaelova Atinska škola (Janson \& Janson, 2004). Na osnovu ovoga, razumno je postulisati da se klasična ideja akademije, koja podrazumijeva odgovornost, iznad i prije svega, prema istini i slobodi govora, te težnju ka utjelovljenju i opravdanoj personifikaciji arhetipa senex, može tumačiti kao arthetipan entitet. Pored činjenice da je ona vijekovima stara društvena institucija, dragocjen ponavljajući obrazac prema definiciji (Huntington, 1968), na ovaj način, akademija predstavlja i primordijalni ideal zajedničke odgovornosti prema istini. 
Neosporno je da postoje promjene $u$ društvenoj strukturi i procesima u odnosu na ranije decenije koje zahtijevaju kombinaciju preduzetničkih i akademskih ciljeva radi efikasne implementacije akademije u zajednici (Clark, Pergamon, \& Clark, 2001). Pored toga što se preduzetnički ciljevi i sistematska standardizacija aktivnosti institucija akademije kose sa prethodno izloženim idealom, specifične studije otkrivaju da ovi vidovi kontrole nad institucijom kao dodatni efekat imaju njeno udaljavanje od akademskog ideala (Mcnay, 2007), te da interes za takozvanu ,akademsku karijeru“ postepeno opada (Roach \& Sauermann, 2017). Riječi živih jezika, naravno, podliježu postepenoj semantičkoj promjeni (Blank, 1990), ali u slučaju kada se radi o riječi koja denominira primordijalni entitet, gubitak originalnog značenja sa sobom nosi i rizik od nestanka ili potiskivanja jednog od ideala čovječanstva. Moglo bi se reći da savremeni svijet zahtijeva evoluciju načina implementacije akademskih institucija, ali takav bi iskaz maliciozno po akademiju sakrio inače očigledno alternativno rješenje: bifurkaciju obrazovnih institucija na one čije je svrha obrazovanje radi maksimizovanja upotrebne vrijednosti za tržište i one čija je svrha obrazovanje radi pomjeranja granica spoznaja, gdje samo drugo ispunjava uslove za nošenje naziva akademija.

Ovdje se prirodno nameće pitanje izvodljivosti takvog vida podjele, ali i, vjerovatno bitnije, pitanje onih procesa koji dovode do toga da se preferira i da je intuitivniji prethodno navedeni maliciozni stav u odnosu na onaj koji bi služio višem cilju. Iako je fundamentalni mehanizam prenosa kulturalnih informacija $u$ oblasti mimetike (Dawkins, 1976) upitan sa semiotičkog stanovišta (Cannizzaro, 2016), ona prezentuje vrlo važnu ideju: jedinice kulture koje mogu da se prenose između različitih domaćina (Fomin, 2019). Semiotički gledano, ovakvi kvantovi kulture ne mogu biti u potpunosti nezavisni od interpretatora, te se rijetko trivijalno kopiraju i, pored toga, kao znakovi generišu dinamičke interpretante koji potencijalno impliciraju informacione hazarde (Bostrom, 2011) za interpretatora. U slučajevima kada se grupe ovakvih znakova mogu enkapsulirati u jedinstvenu semantičku cjelinu na osnovu njihovih dinamičkih i finalnih interpretanata, može se govoriti o implicitnoj ideologiji izraženoj na 


\section{DESTRUKTIVNI UTICAJ POSTHUMANISTIČKE \\ SEMIOTIČKE IDEOLOGIJE NA AKADEMIJU KAO ARHETIPNI ENTITET}

semiotičkom nivou (Keane, 2018). Očigledno, ukoliko postoje grupe znakova koji produkuju slične informacijske hazarde za interpretatore, a one uz to ostaju neregistrovane na svjesnom nivou, njihov efekat po društvo može da bude posebno perniciozan.

Početak dvadeset prvog vijeka u značajnoj mjeri definisan je tehnološkim inovacijama i pronalascima koji su u korijenu promijenili način organizacije društva (OECD, 1999) i omogućili platformu za ekonomski razvoj bez presedana (Rosenberg, 1982) (Mankiw, 2012). S druge strane, ovakva eksplozivna tehnološka ekspanzija u sprezi sa društvenim promjenama produkuje snažne psihološke i socijalne efekte, uključujući uticaje na poremećaje pažnje (Bourchtein, i drugi, 2019) (Ra, Cho, Stone, \& al., 2018), porast učestalosti mentalnih oboljenja (Karim, Oyewande, Abdalla, Ehsanullah, \& Khan, 2020) (Melissa G. Hunt, Marx, Lipson, \& Young, 2018) (Pantic, 2014) uz depresiju (Jr., Ferrucci, \& Duffy, 2015), anksioznost i usamljenost (Eisenberg, Lipson, Heinze, Zhou, \& al., 2020), kao i porast zastupljenosti narcisizma i narcisoidnog poremećaja ličnosti (Vater, Moritz, \& Roepke, 2018) (Twenge \& Campbell, The Narcissism Epidemic, 2010) (Twenge \& Foster, Birth Cohort Increases in Narcissistic Personality Traits Among American College Students, 1982-2009, 2010) (Frederick \& Zhang, 2019) (McCain \& Campbell, 2018), na ovaj način indukujući nove selekcione pritiske. Upotreba i oslanjanje na savremene tehnologije implicitno iziskuje napuštanje starijih pristupa rješavanju odgovarajućih problema, pri čemu su efekti ovakve zamjene relativno nepoznati s obzirom na komparativnu starost ovih tehnologija, pa tako i pristupačnost komunikacionih tehnologija obezbjeđuje novu platformu za propagiranje informacija i mišljenja, te, paradoksalno, utiče na smanjenje pouzdanosti istih informacija (Mitchell, Jurkowitz, Oliphant, \& Shearer, 2020). Dodatno, tehnološki napredak društva korelisan je i sa opadanjem religioznosti i učešća u religijskim obredima (Twenge, Twenge, Exline, \& Grubbs, 2016) (Dogan, 2002) (Brauer, 2018). Ovakva nagla i simultana promjena životnog okruženja za gotovo cijelu ljudsku vrstu, posredovana, u najvećoj mjeri, tehnološkom ekspanzijom, bez obzira na njen percipirani kvalitet, iziskuje i proporcionalno naglu adaptaciju ljudi kao jedinki na nove uslove, kako na fizičkom, tako i na psihološkom 
nivou. Statistički podaci za stope fertiliteta (Department of Economic and Social Affairs, United Nations Secretariat, 2001) kao i za stope stupanja u brak i stope razvoda (Ortiz-Ospina \& Roser, 2020) govore u prilog značajnih promjena selekcionog pritiska. Jači selekcioni pritisak gotovo uvijek (Ueda, Takeuchi, \& Kaneko, 2017) uslovljava brži evolutivni razvoj, pa se, na osnovu prethodno izloženog, može zaključiti da bi pojava ovakvog globalnog pritiska mogla da izazove značajne genetičke promjene, koje bi se prevashodno mogle odraziti na psihološke elemente bića, odnosno na fenomensko iskustvo čovjeka.

Neosporno je da su tehnološke inovacije prethodnog vijeka doprinijele unapređenju životnih standarda na globalnom nivou, te je prirodno očekivati da će se ljudska vrsta adaptirati na novonastale pritiske, ali, sa fenomenološke strane, može da se dovede u pitanje to u kojoj mjeri će tako evoluirano biće predstavljati čovjeka u današnjem smislu i kojih će ideala i tradicija čovjek morati da se odrekne. Iako Hegelove riječi (Hegel, 2011) ne treba olako zanemariti, Duh je u ratu sam sa sobom; on mora da savlada sebe kao svoju najtežu prepreku, kada čovjek paralelno evoluira sa kulturom koja ga, mimetički govoreći, koristi kao domaćina, isti mehanizam koji uzrokuje stagnaciju obezbjeđuje i zaštitu od kulture kao mimetičke prijetnje, koja nikada u istoriji nije imala toliko snažnu platformu za reprodukciju i širenje. $\mathrm{Na}$ sličan način na koji autori upozoravaju na nadolazeću „tehnološku singularnost" (Eden, Moor, Soraker, \& Steinhart, 2012), može da se predvidi i očekuje i odgovarajuća kulturalna singularnost, trenutak u vremenu nakon kog se kulturalne norme, norme ponašanja i osnovni elementi kulture nepredvidivo i nepovratno mijenjaju.

Navedeni argumenti očigledno ukazuju na postojanje ozbiljne prijetnje po čovjeka kao jedinku ukoliko se drži do stava da je ono što čini esenciju čovjeka invarijantno u odnosu na istorijsku epohu, odnosno ukoliko se usvoji konzistentna, vremenski nepromjenljiva, i fenomenološki smislena definicija riječi „čovjek“. Ovdje je naveden zahtjev za fenomenološkim smislom, jer ono što, de facto, označava ljude je upravo njihov kapacitet za prožimanje fenomena smislom, njihova svijest i qualia, ono što čini stvarnost iz subjektivne perspektive onoga ko je u stanju da je iskusi. Bez ovog zahtjeva, svi izneseni 
fenomenološki argumenti gube svoju potentnost, ali priroda sama, bez svijesti kao fenomena, ne mari za očuvanjem bilo kog privremenog disipativnog sistema koji je njen dio i kome bi čovjek mogao da dodijeli ime. Samim tim, bilo koji argument za očuvanje čovjeka u bezfenomenskom kontekstu bi bio besmislen. Iz tog razloga, iako se, formalno govoreći, ovdje radi o argumentu koji bi se mogao klasifikovati kao naturalistička zabluda (Moore, 1922), on ostaje primjenljiv s obzirom na iznesenu metafizičku prirodu problema (Kompridis, 2009). Konačno, izložena prijetnja arhetipnim entitetima ljudske psihe može da se analizira i u kontekstu drugih ovakvih elemenata, uključujući duhovne, religijske i naturalističke obrasce ponašanja, no činjenica da je analitički pristup izlaganju i rješavanju novih problema arhetipni obrazac ponašanja asociran sa idejom akademije sugeriše, doduše ponešto refleksivno, da je očuvanje upravo ove ideje pertinentno za izlaganje vrste i prirode pomenute prijetnje.

\section{POSTHUMANISTIČKA SEMIOTIČKA IDEOLOGIJA}

Posthumanizam, specifično tehnološki posthumanizam, podrazumijeva određen vid negiranja transcendentalnih aspekata ljudske prirode, te izražava međuzavisnost i nerazdvojnost čovjeka od tehnologije, bez obzira na vremensku epohu i kompleksnost te tehnologije (Stiegler, 1998). Dodatno, termin posthumanizam nosi višestruko značenje, uključujući transhumanističku ideologiju koja propovijeda izmjenu čovjeka kao jedinke u interakciji sa tehnologijom, radi njegovog takozvanog usavršavanja, kao i ekstremniju ideju potpune zamjene čovjeka vještačkim organizmima (Ferrando, 2013). Ovakva posthumanistička filosofija, iako očigledno sukobljena sa klasičnim poimanjima čovjeka kao autonomne jedinke, začeta je prije više od jednog vijeka (Nietzsche, 1882) i iznosi neke neosporne kontraargumente klasičnoj humanističkoj filosofiji i sama po sebi, zanemarivši određen nivo idejnog hazarda (Bostrom, 2011), ne ugrožava fenomenološku koncepciju čovjeka u značajno većoj mjeri od drugih savremenih filosofskih pravaca. S obzirom na rečeno, termin 
posthumanizam, može da se odnosi na bilo koji oblik filosofije ili ideologije koja podrazumijeva napuštanje nekih od pretpostavki fenomenološke definicije čovjeka.

U svom najpotentnijem obliku, ideologija se javlja implicitno i skriveno, na nivou na kom izmiče mehanizmima svjesne percepcije, javljajući se svijesti kao lažna a priori kategorija, odnosno namećući sistem interpretacije stvarnosti koga interpretator nije svjestan. Prema Žižekovim riječima (Žižek, 2019) sam koncept ideologije implicira vrstu osnovne, konstitutivne naivnosti: pogrešno prepoznavanje sopstvenih pretpostavki, svojih efektivnih stanja, distancu, divergenciju između takozvane društvene realnosti $i$ naše izobličene reprezentacije, naše lažne svijesti o njoj. U svom ekstremnom obliku, zaposjednutost ideologijom može da dovede do žrtvovanja pojedinca, mimetički posmatrano pretvaranjem individue u mimoid, jedinku koja zanemaruje sopstveni opstanak zarad ili kao posljedicu ideologije (Dawkins, 1976), ili, na civilizacijskom nivou, do pojave rata i sukoba koji su, istorijski gledano, relativno nova društvena tvorevina (Furgerson, 2018). Ovo zanemarivanje sopstvenog opstanka može da se posmatra i na nešto apstraktnijem nivou: smrt jedinke ne mora nužno da bude označena prestankom biološke funkcije tijela, već nestankom fenomenskog iskustva individue čija bi se svijest, tipično dualistički, asocirala sa tim tijelom. Očigledno može da se postavi pitanje u kojoj mjeri svijest može da se izmijeni prije proklamacije fenomenske smrti, čime se, u suštini, ovaj problem svodi na razrješavanje dominantno lingvističkog paradoksa hrpe. Ono što je pertinentno za ovo izlaganje je činjenica da ovakvo pitanje može da se postavi, te da se njime implicitno ukazuje na ideološku prijetnju po određene, prevashodno one primordijalne, aspekte fenomenskog iskustva.

Izmjene $u$ ponašanju, posebno one patološke, koje su nastale uporedo sa razvojem tehnologije ukazuju na potentnost tehnoloških platformi za eksploataciju čovjeka kao domaćina za kulturu, ili, specifičnije i opasnije, ideologiju. Prethodno pomenuti mentalni poremećaji, posebno narcisoidni poremećaj ličnosti i narcisoidnost, razvijaju se, dijelom, kroz rane društvene interakcije (Brummelman, Thomaes, Nelemans, \& al., 2015), koje su, u savremeno doba, sve više 


\section{DESTRUKTIVNI UTICAJ POSTHUMANISTIČKE \\ SEMIOTIČKE IDEOLOGIJE NA AKADEMIJU KAO ARHETIPNI ENTITET}

tehnološki posredovane (Mitchell, Jurkowitz, Oliphant, \& Shearer, 2020) (Weeden, Cooke, \& Mcvey, 2013). Društvene platforme, pored toga što obezbjeđuju propagaciju dezinformacija (Mitchell, Jurkowitz, Oliphant, \& Shearer, 2020), obezbjeđuju i mehanizam za propagaciju gotovo svih vidova informacionih hazarda, no ono što je daleko pernicioznije je njihov potencijal za masovnu indoktrinaciju implicitnom ideologijom razvojnih inženjera koji su im tvorci ili indoktrinaciju manifestujućom ideologijom koja je rezultat tehnoloških ili kulturalnih ograničenja nametnutih istim inženjerima. Pa tako, na primjer, $u$ vezi sa narcisoidnošću, vrlo prirodna pretpostavka je da društvene platforme svojom tehničkom implementacijom indukuju pristrasnost korisnika ka narcisoidnom ponašanju, obezbjeđujući im jednostavan mehanizam za validaciju, poboljšavanje i uljepšavanje lične percepcije fizičkog izgleda, kroz različite funkcionalnosti dijeljenja, uljepšavanja i, iznad svega, filtriranja i selekcije publike, digitalnih fotografija. Iako postoje studije sa različitim rezultatima za konkretan primjer narcisizma (Vater, Moritz, \& Roepke, 2018) (Twenge \& Campbell, The Narcissism Epidemic, 2010) (Twenge \& Foster, Birth Cohort Increases in Narcissistic Personality Traits Among American College Students, 1982-2009, 2010) (Frederick \& Zhang, 2019) (McCain \& Campbell, 2018), vidno je da naizgled naivni i jednostavni izbori pri tehnološkoj implementaciji globalno dostupnog softvera mogu da proizvedu nepredviđene promjene u ponašanju korisnika.

Pored ovakvih direktnih efekata, u sprezi sa kulturom, globalno dostupna tehnologija omogućava integraciju ideologije čiji začetak nije nužno rezultat malicioznih namjera individua ili grupa, već tehnološki asistirane inflacije i naglašavanja određenih prirodnih tendencija čovjeka koje bi, bez pojačavačkog mehanizma globalno dostupne tehnologije, ostajale relativno benigne. Na primjer, vrlo je jasno da propagacija dezinformacija predstavlja problem sa kojim savremeno društvo mora da se nosi, ali ono što ostaje kao skriveni problem je činjenica da je korištenje društvenih mreža u svrhu informisanja o stanju okruženja postalo normativno ponašanje, $s$ obzirom na podatke da je to dominantan način akvizicije vijesti i novosti najmlađih generacija (Mitchell, Jurkowitz, Oliphant, \& Shearer, 2020). Pored ovoga, konstrukcija 
socijalnih platformi je takva da se implicitno signalizira jednakost glasa korisnika samim dizajnom korisničkog interfejsa, iako stvarna implementacija algoritma za odabir publike i evaluaciju glasova nije dostupna krajnjem korisniku. Zanemarivši etički problem implicitne signalizacije demokratije kao ideološke doktrine, jer ona, na nekom nivou, već predstavlja usvojenu ideološku perspektivu, semiotički posmatrano, skriveniji signal, znak, ovakve tehničke implementacije indeksira epistemički relativizam kao implicitno ispravnu doktrinu. Korisnici ovakvih platformi, bez sopstvenog suda i svjesnog procesiranja takve signalizacije, mijenjaju svoje ponašanje proporcionalno nivou ideološkog uticaja. Pored toga, kako se društvene strukture prilagođavaju upotrebi tehnologije, pojavljuje se povratna sprega između tehnologije kao amplifikatora semiotičke ideologije i globalnog društva kao njenog domaćina. Na ovaj način razvija se predominantno semiotička ideologija čiji tvorac je u najvećoj mjeri sama tehnologija kao amplifikator elementarnih ljudskih ponašanja, prevashodno onih najjednostavnijih i najprimamljivijih, sa tendencijom da učini čovjeka u toj mjeri zavisnim od tehnologije da ga tehnološko čini čovjekom više nego biološko, veoma u skladu sa posthumanističkim definicijama (Stiegler, 1998).

Implicitna i podsvjesna signalizacija epistemičkog relativizma predstavlja direktnu prijetnju po ideju o univerzalnoj naučnoj istini, a, samim tim, i po ideju akademije, čiji je osnovni postulat odgovornost prema, između ostalog, i ovoj istini. Uz ovo, manifestacija narcisoidnog ponašanja en masse, odnosno glorifikacija utjelovljavanja jungovskog arhetipa puer eternus, prvenstveno u grupama koje proklamuju zastupanje akademije, direktno se suprotstavlja istom idealu. Naravno, psihoanalitički pristupi ovakvoj problematici ostaju dijelom spekulativni (Žižek, 2019) (Michels, 1999) i nije očigledno da li ovakav vid analize može da se generalizuje na grupe, ali kada se govori o fenomenološkom modelovanju psihe, stabilne i opsežne alternative jungovskoj analizi, pored Lakana (Lacan, 1981) i Kempbela (Campbell, 1973) čije se teorije u određenoj mjeri preklapaju sa jungovskim, gotovo su nepostojeće, pa je razumno posegnuti za najboljim dostupnim modelom. Kako je ideja kolektivnog nesvjesnog genetički osnovana i eksperimentalno provjerljiva (Rosen, Smith, Huston, \& Gonzalez, 2006) (Brown \& 


\section{DESTRUKTIVNI UTICAJ POSTHUMANISTIČKE \\ SEMIOTIČKE IDEOLOGIJE NA AKADEMIJU KAO ARHETIPNI ENTITET}

Hannigan, 2008), razumno je pretpostaviti da su arhetipi kolektivnog nesvjesnog esencijalan element ljudske prirode, onaj koji u velikoj mjeri fenomenima daje smisao (Peterson, 1999).

Prema tome, ukoliko se akademija posmatra kao onaj aspekt psihe čije nestajanje znači izumiranje čovjeka, tada se mimoidom može nazvati svaka osoba indoktrinisana ideologijom koja za cilj ima njeno uništenje, pa je razumno, ukoliko se teži očuvanju dijeljenog fenomenskog iskustva čovjeka, zahtijevati zaštitu ove institucije od takvih individua ili, neminovno pod uticajem tehnologije, takvih grupa.

Kako je ranije izloženo, jedan aspekt ove odbrane mogao bi da bude implementiran razdvajanjem institucija istraživanja i obrazovanja na osnovu njihovog primarnog cilja, odnosno klasifikacijom u dvije kategorije: institucije čiji je cilj optimizacija privrede i institucije čiji je primarni cilj saznanje. Iako bi se, na prvi pogled, moglo pretpostaviti da je pomjeranje granica poznatog neophodan element za usavršavanje, te da, hipotetičkom povratnom spregom, ono pozitivno utiče na privredu, ovakvo posmatranje je u velikoj mjeri zabluda, budući da je pomenuta povratna sprega zasnovana upravo na ideologiji koja definiše način evaluacije uspjeha institucija kroz njihovo ekonomsko djelovanje. Drugim riječima, vrijednost institucije se, društveno gledano, određuje na osnovu njenog ekonomskog učinka, iskazanog kroz njen finansijski potencijal, pa na osnovu ovoga postaje jasnije i da se, posmatrano unutar ove ideološke kutije, saznanje kao cilj vrednuje daleko manje u odnosu na jednostavnu obuku radnika za struku (Brooks, Gupta, Jayadeva, \& Abrahams, 2020), te da ovakav vid implementacije akademije, bez obzira na finansijsku jačinu sprege sa privredom, koja je tipično relativno slaba (National Science Board, 2018) (OECD (2021), 2021) (Atkinson \& Foote, 2019), na nju ne djeluje nužno pozitivno (Bloch \& Sørensen, 2015) (Jacob \& Lefgren, 2011) (Larson, Ghaffarzadegan, \& Diaz, 2012) (Bauwens Luc, 2011) (Gök, Rigby, \& Shapira, 2016) (Archer, 2020). Naravno, stvarni problem je ovdje sakriven, jer je implicitna sugestija da se svojevrsnom „Ptolomizacijom“ (Žižek, 2019) može doći do ispravnog rješenja, dok stvarno rješenje podrazumijeva promjenu osnovne perspektive na problem. Nota bene, implicitni ideološki imperativ ovdje je da orijentisanje ka učeniku i njegovim 
potrebama, odnosno, manje ideološki opfuskovano, potrebama privrede i tržišta za radnom snagom indeksiranom riječju ,učenik“, treba da se preferira u odnosu na bilo kakav transcendentalni ideal, slično kao i orijentisanje ka optimizaciji privrednog učinka. Relativno trivijalna ilustracija ovakvog vida semiotičkog signaliziranja je u samom pristupu evaluaciji osoblja i nastavnih $i$ istraživačkih procesa koji semiotički indeksira „ispravan“ način razmišljanja odabirom, odnosno izuzimanjem, i formulacijom anketa za evaluaciju - nepostojanje pitanja koja se odnose na principe akademije, etičku odgovornost prema idealu akademije, i lično, subjektivno, mišljenje akademskog osoblja u vezi sa smjerom $\mathrm{u}$ kom akademija treba da se razvija implicitno sakriva postojanje takvih problema i nameće ideološki okvir kroz koji ispitanici treba da interpretiraju realnost. Naravno, ovaj vid signalizacije (e.g. (Gallup, 2018), (Dimova, Stoyanova, Harizanova, Tarnovska, \& Keskinova, 2019), (Santa Monica College, 2017), (Western Kentucky University, 2008) i (Hanover Research, 2012)) nije specifičan samo za univerzitetske ankete i relativno nezavisan posmatrač bi mogao da postavi uopštenije pitanje odnosa mjere u kojoj je formulacija sadržaja društvenih anketa svjesno planirana i mjere u kojoj je ona jednostavna replikacija najčešće prisutnih obrazaca konstrukcije koji su, kako je već izloženo, dominantno tehnološki propagirani i predstavljaju amplifikacije nepotpunih fragmenata rudimentarnih kvaziideala mase. Bez obzira na uzrok, institucija akademije prema ranije definisanim postulatima nije održiva unutar okvira usvojene semiotičke ideologije. Njeno očuvanje zahtijeva emancipaciju, a budući da bi izmjena novoustanovljene, odnosno ideološki adaptirane, institucije zahtijevala fundamentalnu izmjenu društvene strukture, praktičnije rješenje je ranije predložena bifurkacija izvedena ne nužno na pravnom nivou, koji bi implicirao određen vid „Ptolomizacije“, koliko na nivou individualnog djelovanja.

\section{EKSPLOATACIJA GLOBALNO DOSTUPNE TEHNOLOGIJE}

Prema Bernejsovim riječima (Bernays, 1928, str. 9), svjesna $i$ inteligentna manipulacija organizovanih navika $i$ mišljenja mase je 


\section{DESTRUKTIVNI UTICAJ POSTHUMANISTIČKE \\ SEMIOTIČKE IDEOLOGIJE NA AKADEMIJU KAO ARHETIPNI ENTITET}

važan element demokratskog društva. Oni koji manipulišu ovaj nevidljivi mehanizam društva čine nevidljivu vlast. Propaganda kao mehanizam kontrole populacije jedan je od glavnih uzroka onoga što Čomski naziva Orvelovim problemom, odnosno činjenice da je šira populacija relativno neinformisana ili dezinformisana uprkos globalnoj i lakoj dostupnosti informacija. Čomski uočava (Noam Chomsky, 1986, str. xxvii) da moramo otkriti institucijske $i$ druge faktore koji blokiraju saznanje $i$ razumijevanje u ključnim oblastima naših života i postaviti pitanje zašto su efektivni.

Kada se u obzir uzme globalno dostupna tehnologija i semiotički način kojim ona propagira ideologiju, postaje jasno da ,nevidljivu vlast“ ne moraju nužno da čine samo ljudi, već je ona dijelom utjelovljena $u$ upravljačkim mehanizmima i algoritmima tehnoloških platformi koje su de facto postale primarni način komunikacije i organizacije društvenog djelovanja. Naravno, poznato je da su određeni elementi društvenih mreža konstruisani tako da eksploatišu ljudsku prirodu i kreiraju zavisnost (Schwär \& Moynihan, 2020) (Lewis, 2017) (Andersson, 2018) (Levin, 2017) korištenjem operantnog uslovljavanja, ali daleko opasniji aspekt globalne upotrebe ovih platformi je što one, uz signalizaciju epistemičkog relativizma, obezbjeđuju grupisanje individua u kohorte na osnovu nekog zajedničkog cilja ili mišljenja. Na prvi pogled, ovakva mogućnost mogla bi se smatrati izrazito poželjnom, ali sa stanovišta propagande ona obezbjeđuje lak način za masovnu manipulaciju, šta god bio inicijalni izvor kontrole. Pored toga što obezbjeđuje mehanizam za agregaciju i, potom, manipulaciju većih grupa, globalno dostupna tehnologija obezbjeđuje i mehanizam kontrole manjih grupa otpornijih na manipulaciju eksploatacijom usvojene demokratske doktrine tako da se, sada suštinski irelevantno, njihovo mišljenje potiskuje dominacijom mišljenja većinskih manipulisanih grupa.

Čak i kada se radi o platformama čija primarna namjena nije grupisanje, kao što je slučaj sa platformama za dijeljenje video-sadržaja, implicitna signalizacija epistemičkog relativizma i pritisak za konformaciju većinskom mišljenju postaju evidentni kada se u obzir uzme činjenica da se paneli za evaluaciju uspješnosti nekog objavljenog sadržaja baziraju na prebrojavanju publike. Na ovaj način, autorima se 
sugeriše i ograničava oblik i način komunikacije sa publikom, te se, kao postepen proces sa povratnom spregom, ideološki indoktriniše autor i otuđuje ili indoktriniše dio publike specifično vezan za užu tematiku, zarad proširenja na širu publiku signaliziranog kao ispravnog. Ovakvim pritiscima iskorjenjuje se ne samo raznolikost ideja, već se indirektno ograničava sloboda govora, sužavanjem slobode misli.

Poznato je da psihometrijska inteligencija u određenoj mjeri utiče na političke odluke (Rindermann, Flores-Mendoza, \& Woodley, 2012), no relevantnija je činjenica da je podložnost sugestiji sa njom inverzno korelisana (Gudjonsson, 1983) (Gignac \& Powell, 2006) (McFarlane, Powell, \& Dudgeon, 2002). Kako psihometrijska inteligencija prati Gausovu raspodjelu, očigledno je da globalno dostupne tehnologije obezbjeđuju mehanizam za potiskivanje mišljenja upravo onih grupa koje se nalaze na gornjem kraju ove distribucije, što velikim dijelom podrazumijeva upravo onaj dio populacije naklonjen akademiji (Hauser, 2002) (Seligman, 1992).

Izrazito perniciozan aspekt ovog pristupa je, ponovo, semiotička signalizacija etičke ispravnosti grupne organizacije radi političkog ili društvenog djelovanja zarad ciljeva grupe, koji, u realnosti, predstavljaju ciljeve odvojenog entiteta koji ispoljava kontrolu nad grupom. Naklonjenost individue ka prihvatanju identiteta grupe bi, na osnovu prethodnog izlaganja, mogla da obezbijedi platformu za eksploataciju rodbinske selekcije i na taj način omogući regrutaciju mimoida za svrhu ostvarivanja političkih ciljeva ili implicitnog društvenog inženjeringa.

Iako se savremena institucija akademije suočava i sa problemima ponovljivosti rezultata publikacija (Prinz, Schlange, \& Asadullah, 2011) (Baker, 2016), kao i sistemske pristrasnosti ka neoriginalnosti (Wang, Veugelers, \& Stephan, 2017) koji ne mogu lako da se redukuju na jedan uzrok, perzistentna glorifikacija narcisoidnog ponašanja i neosnovana inflacija ega i zasluge za validaciju, odnosno upravo onih osobina enkapsuliranih tipom puer eternus, vrlo očigledno ima za posljedicu stvaranje pojedinaca čije djelovanje je takvo da traže samo krajnji efekat društvene validacije, bez ulaganja truda $u$ sopstvenu izgradnju i usavršavanje. Ovo ponašanje je, naravno, u skladu sa ljudskom prirodom, ali amplifikovano do trenutnih razmjera vrlo očigledno može 
da dovede do korupcije, plagijarizma i sveopšte degradacije moralnih načela, što je evidentno iz velikog broja studija koje sugerišu da učestalost prevara za vrijeme studija, koja je u porastu (Kirya, 2019), prelazi i $80 \%$ (Witherspoon, Maldonado, \& Lacey, 2010) (Bjorklund \& Wenestam, 1999) (Owunwanne, Rustagi, \& Dada, 2010), te da se ovakvo ponašanje, pored nekažnjavanja, implicitno nagrađuje, analogno operantnom uslovljavanju, pri čemu ovakav vid socijalnog inženjeringa nije nužno planiran od strane onih koji izvode uslovljavanje, već implicitan i sproveden u djelo semiotičkim mehanizmima.

Očigledno, individue koje su neautonomni saučesnici u ovom procesu, ne predstavljaju ništa više od mimoida, avatara posthumanističke semiotičke ideologije, agente sistema koji, zbog svoje neautonomnosti, prema definiciji akademije, njoj ne mogu da pripadaju. Naravno, deklarisati imunitet na ove ideološke uticaje, posebno kada su oni pojačani savremenim društvenim platformama, bila bi naivna zabluda (Žižek, 2019) (Bernays, 1928), pa se nameće neizbježan zaključak o epidemijskom potencijalu i karakteru ovih uticaja, odnosno o razini njihovog informacionog hazarda. Stoga, djeluje da se pojedincu koji traži da sačuva lični integritet $i$, paradoksalno, ideal akademije nameće samo rješenje da novonastalu instituciju napusti pod prijetnjom propadanja ličnosti i načela.

\section{SUVERENA I AUTOHTONA INSTITUCIJA AKADEMIJE}

Neosporno, ovakav vid rasprave oslanja se na određene aksiomatske etičke pretpostavke, konkretno da fenomenski dio ljudskog iskustva, i onaj dio psihe koji fenomenima daje smisao i vrijednost, predstavljaju kategorije koje vrijedi očuvati, i, prema tome, nerazumno bi bilo tvrditi da emancipacija od pomenute posthumanističke ideologije ne predstavlja po sebi samo drugačiji vid ideologije. S druge strane, uprkos postmodernističkim argumentima, neke istine ostaju transcendentalne - analogno Dekarteovom je pense, donc je suis (Descartes, 1637), bilo koji entitet koji konstituiše svijest može da tvrdi da nešto postoji i ta tvrdnja je neizbježno fenomenskog karaktera. Naravno, pitanje ontološkog statusa fenomena je otvoreno i u izrazitoj 
mjeri utiče na ovakav oblik argumenta, ali zanemariti fenomenološki argument zbog epistemičke neizvijesnosti ovog odgovora bi značilo ne sagledati problem u njegovoj cjelini. Izložena ideološka prijetnja je dokazivo potentna, te je pored samog izlaganja problema neophodno pronaći rješenja koja obezbjeđuju očuvanje ne samo akademskih već i ostalih primordijalnih ideala ovaploćenih u ljudskoj psihi, uprkos ideološkim pritiscima.

Ukoliko je jungovska interpretacija fenomena na dobrom tragu, razumno je očekivati da, bez obzira na nivo ideološke indoktrinacije, dok god mu ideali nisu genetički potisnuti, zdrav čovjek ima tendenciju da spontano vrednuje primordijalne ideale, te da teži da ih utjelovi (Peterson, 1999). Na ovaj način, utjelovljenje primordijalnog ideala u ponašanju i djelu mora da ima isti ili intenzivniji viralni karakter kao i silom propagirana ideologija. Podsvjesni mehanizmi ljudske psihe razvili su se da detektuju i validiraju pozitivnost ovakvog ponašanja (Peterson, 1999), pa je upravo ono to koje ima šansu da odagna pritiske semiotičke ideologije, budući da ovi mehanizmi operišu na istom nivou svijesti kao i ona. Sviješću o nesvjesnom i onom a priori, čovjeku je dato oruđe kojim da se brani i opire pritiscima koje nije u stanju svjesno da percipira.

$\mathrm{Na}$ ovaj način dolazi se do rješenja za problem podjele akademske institucije sa ciljem očuvanja akademskog ideala: kako je institucija obrazac ponašanja, disipativni sistem kog ne čine individualni ljudi, zdanja i zapisi, već kolektivno ispoljeno ponašanje i ako se smatra da ideali asocirani za instituciju akademije predstavljaju primordijalne ideale koji mogu da se utjelove ponašanjem, tada njeno očuvanje ovisi samo o očuvanju arhetipnog ponašanja sa njom $u$ vezi. Paradoksalno, birokratski mehanizmi ideološki služe sakrivanju ove činjenice, tajno služeći suprotnom cilju.

Iz ovog razloga, onaj ko strijemi ka akademskom idealu, preuzima odgovornost ne samo da u djelo sprovede njene principe, već da se emancipira od procesa koji će dovesti do degradacije njegovog ponašanja i efektivno ga učiniti mimoidom. Ukoliko se argument dovede do svog ekstremnog zaključka, ako su ovi principi u istom panteonu sa primordijalnim božanstvima, tada je vrhovni i suvereni cilj njih iskazati, makar i na ličnu štetu i pogotovo onda kada je ta šteta postojana samo 


\section{DESTRUKTIVNI UTICAJ POSTHUMANISTIČKE \\ SEMIOTIČKE IDEOLOGIJE NA AKADEMIJU KAO ARHETIPNI ENTITET}

unutar ideološkog okvira koji bi, kada bi svako ko proklamuje akademske težnje njih istinski iskazao, bio nepostojeći. Uzevši u obzir Kantov kategorički imperativ (Kant, 1785), djeluj prema onoj maksimi prema kojoj možeš istovremeno željeti da ona postane univerzalni zakon, prethodni stav postaje utoliko važniji, jer zahtijeva od pojedinca koji teži da utjelovi primordijalni obrazac ponašanja da to uradi na takav način koji omogućava, i ne inhibira, takav isti pristup. Drugim riječima, utjeloviti akademski ideal moguće je samo pod uslovom da se odbije saradnja sa implicitno signaliziranim dogmatskim praksama posthumanističke ideologije, što sa sobom prirodno povlači određene društvene rizike, unutar okvira iste ideologije.

Naravno, otvoreno protestovanje, opiranje indoktrinaciji i vokalizacija opozicije semiotičkim i drugim mehanizmima ideološke indoktrinacije, kao i drugi vidovi „Ptolomizacije“ predstavljaju potreban, ali ne dovoljan, uslov za razrješenje problema. Stvarno razrješenje zahtijeva intelektualnu emancipaciju iz korumpiranog sistema, odnosno povratak iskonskim akademskim idealima, slično ili, pak, identično originalnoj platonskoj akademiji. Ovo podrazumijeva odbijanje djelovanja koje se kosi sa akademskim idealom, čak i unutar institucija ideološki prisilno asociranim sa njim.

Na ovaj način, originalna institucija akademije postaje izdvojena od savremenih institucija visokog obrazovanja i živi kao emergentni entitet, epifenomenska institucija, manifestovana individualnim djelovanjem pojedinaca koji svojom autonomnom odlukom iskazuju iskonske principe čovječanstva, istinski imune na ideološke pritiske. Ovako akademija nije samo još jedna grupa, već svjestan entitet sa identitetom nezavisnim u odnosu na identitete onih koji ga čine stvarnim.

Na prvi pogled, ovakav vid postupanja djeluje uzaludan, no on je jedini dovoljno viralan da sačini mimetičku kontratežnju postojećim strujama. Akademija nikada nije predstavljala širok krug, i, uprkos nepopularnosti ovakve tvrdnje, to svakako nije njena arhetipna slika, pa njeno rasparčavanje sa sobom nužno ne nosi negativne posljedice po nju samu. Bez obzira, ako je suditi po znakovima psihološkog disbalansa manifestovanog porastom mentalnih oboljenja, savremeni čovjek čezne za duhovnim utemeljenjem, pa se ovakav optimizam i ne čini odveć 
naivnim, uprkos prividnoj, ili možda implicitno signaliziranoj, uzaludnosti istog.

Neizbježan zaključak je da da bi institucija akademije istinski bila autohtona i nezavisna, oni koji je čine moraju biti odani njenom idealu i autonomni u svom djelovanju, a to nije izvedivo ili, barem, održivo, unutar tekućeg ideološkog okvira, pa se ona mora postupanjem prema idealu sprovesti u djelo izvan njega.

\section{ZAKLJUČAK}

Genetički gledano, jedinka koju predstavlja savremeni čovjek, sa bihevioralne strane ostaje suštinski ista posljednjih nekoliko stotina godina. S druge strane, milioni godina evolucije koji prethode nastanku savremenog čovjeka obezbijedili su nastajanje obrazaca ponašanja i psiholoških a priori sudova kojima čovjek djeluje u svom okruženju i na osnovu kojih interpretira realnost. Pored toga, uz razvoj jezika (Chomsky, 2000), čovjek je razvio i način da predstavlja i tumači svijet narativno, oslanjajući se na primordijalne slike i ideale ugrađene na genetskom nivou i manifestovane u stvarnost na fenomenskom kao glasovi savjesti i težnje ka apstraktnim idealima.

S druge strane, savremena tehnologija obezbjeđuje platformu za propagaciju vještački indukovane posthumanističke ideologije čija se načela podsvjesno propagiraju semiotičkim mehanizmima pod velom etičkog i epistemičkog napretka i koja su u sukobu sa tradicionalnim, primordijalnim. Ova posthumanistička ideologija uzrokuje disparitet na psihološkom i sociološkom nivou i predstavlja mehanizam kontrole i indoktrinacije individue nametanjem ideološkog okvira i ograničavajući kapacitet za slobodnu misao usputno pretvarajući doskora slobodne pojedince $u$ agente svoje propagande i regrutujući ih implicitno u svrhu potiskivanja tradicionalnih vrijednosti i mijenjajući prirodu selekcionog pritiska.

Kako se značajne evolutivne promjene događaju pri značajnim promjenama selekcionog pritiska, nije nerazumno očekivati relativno brzu promjenu na genetičkom nivou, odnosno potiskivanje tradicionalnih ideala ne samo na nivou trenutne populacije, već i na genetičkom nivou, 


\section{DESTRUKTIVNI UTICAJ POSTHUMANISTIČKE \\ SEMIOTIČKE IDEOLOGIJE NA AKADEMIJU KAO ARHETIPNI ENTITET}

pa, iz tog razloga, ovakva semiotička ideologija predstavlja prijetnju po fenomensko iskustvo čovjeka, odnosno po samu njegovu prirodu.

Akademska institucija tradicionalno se zasniva na idejama slobode govora, spoznavanja neznanog i kritičkog i dijalektičkog razmatranja dostupnih činjenica, te je utemeljena u principima ličnog usavršavanja i unapređenja, u skladu sa najstarijim idealima koji nastanjuju kolektivno nesvjesno. Kao takva, ona se nalazi na sudaru dvaju ideoloških težnji, jedne tradicionalne, one duhovne i iskonske $\mathrm{i}$ druge savremene, posthumanističke, jer je, prema svojoj definiciji, jedina koja posjeduje kapacitet i oruđa da te dvije perspektive pomiri. Paradoksalno, pod uticajem savremene globalno dostupne tehnologije i društvenih platformi, institucija akademije, oličenje slobodne misli i glasa razuma, povinuje se ideološkim uticajima i prijeti napuštanjem sopstvenog ideala. Istrebljenje ovog ideala sa sobom povlači nemogućnost odbrane bilo kog drugog, jer se upravo u ovome i nalazio mehanizam te odbrane. Iz tog razloga, ako je cijeniti ljudsko fenomensko i ako je razumno zahtijevati očuvanje onoga što zadnjih stotinu hiljada godina fenomenski čini čovjeka čovjekom, razumno je i zahtijevati odbranu ovog ideala.

S obzirom na postojanje implicitnog ideološkog okvira kojim se u savremenom društvu čovjeku ograničava djelovanje, iskazivanje akademskog ideala postaje u velikoj mjeri nemoguće ili, barem, ograničeno. Rješenje problema zahtijeva potpunu promjenu osnovne perspektive na savremeni život, što, vrlo vjerovatno, podrazumijeva promjenu političke, ekonomske i društvene strukture, što je gigantski zahvat nepremostiv pojedincu. Bez obzira na mračnu perspektivu, onome ko teži akademskom idealu i očuvanju integriteta sopstvenog karaktera pred nemilosrdnim indoktrinišućim uticajima posthumanističke ideologije, ostaje da te ideale utjelovi i svojim djelima vrati u stvarnost, makar po cijenu osude unutar dogmatizovanog sistema, pa čak i pod implicitno signaliziranim rizikom od napuštanja novoadaptirane institucije, jer alternativni rizik je gubitak intelektualne i fenomenske autonomnosti.

Uprkos podsvjesnoj semiotičkoj signalizaciji ispravnosti posthumanističke misli, transcendentalni ideali čovječanstva postoje na 
nivou kolektivnog nesvjesnog i predstavljaju potentan mehanizam za viralno prenošenje upravo onih ideja koje su uskladu sa tim idealima, što pored odgovornosti za očuvanje sopstvenog intelektualnog suvereniteta, daje svakome ko nezavisno, opravdano i posvećeno teži ka utjelovljenju akademskog ideala nadu da se ta težnja podsvjesno i implicitno vrijednuje i da djelovanje ka njegovoj zaštiti samo po sebi predstavlja transcendentalan cilj vrijedan ostvarivanja.

\section{LITERATURA}

Abbot, P., Abe, J., Alcock, J., Alizon, S., \& al., e. (2011). Inclusive fitness theory and eusociality. Nature, 471(7339).

Alexey, E. (2005). Noogenesis and Theory of Intellect. 2005. - 356 p. Еремин А. Л. Ноогенез и теория интеллекта. Краснодар: СовКуб, 2005. $356 \mathrm{c}$.

Andersson, H. (2018). Social media apps are 'deliberately' addictive to users. BBC.

Archer, E. (2020). The Intellectual and Moral Decline in Academic Research. The James G. Martin Center for Academic Renewal.

Atkinson, R. D., \& Foote, C. (2019). U.S. Funding for University Research Continues to Slide. Information Technology \& Innovation Foundation.

Baker, M. (2016). 1,500 scientists lift the lid on reproducibility. Nature, 533(7604), 452-454.

Bauwens Luc, M. G.-F. (2011). The Resistible Decline of European Science. Recherches économiques de Louvain, 77, 5-31.

Behjati, S., \& Tarpey, P. S. (2013). What is next generation sequencing? Archives of Disease in Childhood. Education and Practice Edition, 98(6), 236-238.

Bernays, E. (1928). Propaganda. Routlege.

Bjorklund, M., \& Wenestam, C. (1999). Academic cheating: frequency, methods, and causes. European Conference on Educational Research. Lahti, Finland.

Blank, A. (1990). Why do new meanings occur? A cognitive typology of the motivations for lexical semantic change. Historical Semantics and Cognition, 61-90.

Bloch, C., \& Sørensen, M. P. (2015). The size of research funding: Trends and implications. Science and Public Policy, 42(1), 30-43. 
Bostrom, N. (2011). Information Hazards: A Typology of Potential Harms from Knowledge. Review of Contemporary Philosophy, 10, 44-79.

Bourchtein, E., Langberg, J. M., Cusick, C. N., Breaux, R. P., Smith, Z. R., \& Becker, S. P. (2019). Featured Article: Technology Use and Sleep in Adolescents With and Without Attention-Deficit/Hyperactivity Disorder. Journal of Pediatric Psychology, 44(5), 517-526.

Bower, J. M. (2003). Rethinking the "Lesser Brain". Scientific American, 289(2), 50-57.

Brauer, S. (2018). The Surprising Predictable Decline of Religion in the United States. Journal for the Scientific Study of Religion, 57(4), 654-675.

Brooks, R., Gupta, A., Jayadeva, S., \& Abrahams, J. (2020). Students' views about the purpose of higher education: a comparative analysis of six European countries. Higher Education Research \& Development, 1-14.

Brown, J. M., \& Hannigan, T. P. (2008). An Empirical Test of Carl Jung's Collective Unconscious (Archetypal) Memory. Journal of Border Educational Research, 5, 114-128.

Brummelman, E., Thomaes, S., Nelemans, S. A., \& al., e. (2015). Origins of narcissism in children. Proceedings of the National Academy of Sciences, 112(12), 3659-3662.

Campbell, J. (1973). The Hero With A Thousand Faces. Princeton University Press.

Cannizzaro, S. (2016). Internet memes as internet signs: A semiotic view of digital culture. Sign Systems Studies, 44(4), 562.

Casali, A. G., Gosseries, O., Rosanova, M., \& al., e. (2013). A Theoretically Based Index of Consciousness Independent of Sensory Processing and Behavior. Science Translational Medicine, 5(198), 198.

Chardin, P. T. (1955). The Phenomenon of Man. Harper Perennial.

Chomsky, N. (2000). New Horizons in the Study of Language and Mind. Cambridge University Press.

Clark, B. R., Pergamon, B. R., \& Clark, B. C. (2001). Creating Entrepreneurial Universities: Organizational Pathways of Transformation. Emerald Publishing Limited.

Courten-Myers, G. M. (1999). The human cerebral cortex: gender differences in structure and function. Journal of neuropathology and experimental neurology, 58(3), 217-226.

Dancy, R. M. (1991). Two Studies in the Early Academy. State University of New York Press.

Dawkins, R. (1976). The Selfish Gene. Oxford University Press. 
Demertzi, A., Tagliazucchi, E., Dehaene, S., \& al., e. (2019). Human consciousness is supported by dynamic complex patterns of brain signal coordination. Science Advances, 5(2).

Department of Economic and Social Affairs, United Nations Secretariat. (2001). Fertility Levels and Trends in Countries with Intermediate Levels of Fertility. United Nations.

Descartes, R. (1637). Discourse on the Method of Rightly Conducting One's Reason and of Seeking Truth in the Sciences. BnF Gallica.

Dimova, R., Stoyanova, R., Harizanova, S., Tarnovska, M., \& Keskinova, D. (2019). Academic Staff Satisfaction with their Work: A CrossSectional Study in a Medical University. Open access Macedonian journal of medical sciences, 7(14), 2384-2390.

Dogan, M. (2002). Accelerated Decline of Religious Beliefs in Europe. Comparative Sociology, 1(2), 127-149.

Eden, A. H., Moor, J. H., Soraker, J. H., \& Steinhart, E. (2012). Singularity Hypotheses: A Scientific and Philosophical Assessment. Springer.

Edinger, E. F. (1992). Ego and Archetype. Shambhala.

Eisenberg, D., Lipson, S. K., Heinze, J., Zhou, S., \& al., e. (2020). The Healthy Minds Study: Fall 2020 Data Report. Healthy Minds Network.

Ferrando, F. (2013). Posthumanism, Transhumanism, Antihumanism, Metahumanism, and New Materialisms Differences and Relations. Existenz, 8(2), 26-32.

Fischer, D. B., Boes, A. D., Demertzi, A., \& al., e. (2016). A human brain network derived from coma-causing brainstem lesions. Neurology, 87(23), 2427-2434.

Fomin, I. (2019). Memes, genes, and signs: Semiotics in the conceptual interface of evolutionary biology and memetics. Semiotica, 2019(230).

Frederick, C. M., \& Zhang, T. (2019). Narcissism and Social Media Usage: Is There No Longer a Relationship? Journal of Articles in Support of the Null Hypothesis, 16(1), 23-32.

Frye, N. (1957). Anatomy of Criticism: Four Essays. Princeton University Press. Furgerson, R. B. (2018). Why We Fight. Scientific American, 319(3), 76-81.

Gallup. (2018). The AGB 2018 Trustee Index. Gallup.

Gignac, G. E., \& Powell, M. B. (2006). A direct examination of the nonlinear (quadratic) association between intelligence and suggestibility in children. Applied Cognitive Psychology, 20(5), 617-623.

Gök, A., Rigby, J., \& Shapira, P. (2016). The Impact of Research Funding on Scientific Outputs: Evidence from Six Smaller European Countries. 


\section{DESTRUKTIVNI UTICAJ POSTHUMANISTIČKE \\ SEMIOTIČKE IDEOLOGIJE NA AKADEMIJU KAO ARHETIPNI ENTITET}

Journal of the Association for Information Science and Technology, 67(3), 715-730.

Gudjonsson, G. H. (1983). Suggestibility, intelligence, memory recall and personality: an experimental study. British Journal of Psychiatry, 142, 35-37.

Hamilton, W. D. (1964). The genetical evolution of social behaviour. Journal of Theoretical Biology, 7(1), 1-16.

Hanover Research. (2012). Assessing Faculty and Staff Satisfaction Prepared for the University of Alaska Anchorage. Hanover Research.

Harari, Y. N. (2017). Homo Deus: A Brief History of Tomorrow. Harper.

Hauser, R. M. (2002). Meritocracy, cognitive ability, and the sources of occupational success. The University of Wisconsin-Madison.

Hegel, G. W. (2011). Lectures on the Philosophy of History. WordBridge Publishing.

Henshilwood, C. S., \& Marean, C. W. (2003). The origin of modern human behavior: Critique of the models and their test implication. Current Anthropology, 44, 627-651.

Herculano-Houzel, S. (2009). The Human Brain in Numbers: A Linearly Scaled-up Primate Brain. Frontiers of Human Neuroscience, 3(31).

Herculano-Houzel, S. (2012). Brain Evolution. In The Human Nervous System (pp. 2-13). ClinicalKey.

Hoffman, D. (2008). Conscious realism and the mind-body problem. Mind and Matter, 6(1), 87-121.

Huntington, S. P. (1968). Political Order in Changing Societies. Yale University Press.

Jacob, B. A., \& Lefgren, L. (2011). The impact of research grant funding on scientific productivity. Journal of Public Economics, 95(9-10), 11681177.

Janson, H. W., \& Janson, A. F. (2004). History of Art: The Western Tradition. Prentice Hall Professional.

Jr., E. C., Ferrucci, P., \& Duffy, M. (2015). Facebook use, envy, and depression among college students: Is facebooking depressing? Computers in Human Behavior, 43, 139-146.

Jung, C. (1959). Aion: Researches Into the Phenomenology of the Self. Routledge.

Jung, C. G. (1968). Man and His Symbols. Dell Publishing Co., Inc.

Jung, C. G. (1976). Psychological Types. Princeton University Press.

Jung, C. G. (1991). The Archetypes and the Collective Unconscious. Routledge. 
Jung, C. G. (2014). Four Archetypes. Routledge.

Jung, C. G. (2014). The Collected Works of C.G. Jung. Princeton University Press.

Kant, I. (1785). Grundlegung zur Metaphysik der Sitten. Riga, J.F. Hartknoch.

Karim, F., Oyewande, A. A., Abdalla, L. F., Ehsanullah, R. C., \& Khan, S. (2020). Social Media Use and Its Connection to Mental Health: A Systematic Review. Cureus, 12(6).

Keane, W. (2018). On Semiotic Ideology. Signs and Society, 6(1).

Kirya, M. (2019). Corruption in universities: Paths to integrity in the higher education subsector. Chr. Michelsen Institute.

Kompridis, N. (2009). Technology's Challenge to Democracy: What of the Human? Parrhesia, 8, 20-33.

Kurzban, R., Burton-Chellew, M. N., \& West, S. A. (2015). The Evolution of Altruism in Humans. Annual Review of Psychology, 66, 575-599.

Lacan, J. (1981). Speech and Language in Psychoanalysis. The Johns Hopkins University Press.

Laland, K. N. (2008). Exploring gene-culture interactions: insights from handedness, sexual selection and niche-construction case studies. Philosophical Transactions of the Royal Society B, 363(1509), 35773589.

Larson, R. C., Ghaffarzadegan, N., \& Diaz, M. G. (2012). Magnified Effects of Changes in NIH Research Funding Levels. Service science, 4(4), 382395.

Levin, S. (2017). Facebook told advertisers it can identify teens feeling 'insecure' and 'worthless'. The Guardian.

Lewis, P. (2017). 'Our minds can be hijacked': the tech insiders who fear a smartphone dystopia. The Guardian.

Lindberg, D. C. (2008). The Beginnings of Western Science. University of Chicago Press.

Lister, A. M. (2013). The role of behaviour in adaptive morphological evolution of African proboscideans. Nature, 500, 331-334.

Lui, J. H., Hansen, D. V., \& Kriegstein, A. R. (2011). Development and Evolution of the Human Neocortex. Cell, 146(1), 18-36.

Mankiw, N. G. (2012). Principles of macroeconomics. South-Western Cengage Learning.

McCain, J. L., \& Campbell, W. K. (2018). Narcissism and Social Media Use: A Meta-Analytic Review. Psychology of Popular Media Culture, 7(3), 308-327. 


\section{DESTRUKTIVNI UTICAJ POSTHUMANISTIČKE \\ SEMIOTIČKE IDEOLOGIJE NA AKADEMIJU KAO ARHETIPNI ENTITET}

McFadden, J. (2020). Integrating information in the brain's EM field: the cemi field theory of consciousness . Neuroscience of Consciousness, 2020(1).

McFarlane, F., Powell, M. B., \& Dudgeon, P. (2002). An examination of the degree to which IQ, memory performance, socio-economic status and gender predict young children's suggestibility. Legal and Criminological Psychology, 7(2), 227-239.

Mcnay, I. (2007). Values, Principles and Integrity: Academic and Professional Standards in Higher Education. Journal of Higher Education Policy and Management, 19(3).

Melissa G. Hunt, Marx, R., Lipson, C., \& Young, J. (2018). No More FOMO: Limiting Social Media Decreases Loneliness and Depression. Journal of Social and Clinical Psychology, 37(10), 751-768.

Michels, R. (1999). Psychoanalysis and Psychiatry: A Changing Relationship. American Mental Health Foundation.

Mitchell, A., Jurkowitz, M., Oliphant, J. B., \& Shearer, E. (2020). Americans Who Mainly Get Their News on Social Media Are Less Engaged, Less Knowledgeable. Pew Research Center.

Monti, M. M., Vanhaudenhuyse, A., Coleman, M. R., \& al., e. (2010). Willful Modulation of Brain Activity in Disorders of Consciousness. The New England Journal of Medicine, 362, 579-589.

Moore, G. E. (1922). Principia Ethica. Cambridge University Press.

National Science Board. (2018). Science and Engineering Indicators 2018 (NSB-2018-1) . National Science Foundation.

Nietzsche, F. (1882). Die fröhliche Wissenschaft. Chemnitz : Ernst Schmeitzner.

Noam Chomsky. (1986). Knowledge of Language: Its Nature, Origin, and Use. Praeger Special Studies.

OECD (2021). (2021). Gross domestic spending on R\&D (indicator). OECD.

OECD. (1999). 21st Century Technologies: Promises and Perils of a Dynamic Future. Organisation for Economic Co-operation and Development.

Ortiz-Ospina, E., \& Roser, M. (2020). Marriages and Divorces. Our World in Data.

Owen, A. M., Coleman, M. R., Boly, M., \& al., e. (2006). Detecting Awareness in the Vegetative State. Science, 313(5792), 1402.

Owunwanne, D., Rustagi, N. K., \& Dada, R. (2010). Students Perceptions Of Cheating And Plagiarism In Higher Institutions. Journal of College Teaching and Learning, 7(11). 
Pantic, I. (2014). Online Social Networking and Mental Health. Cyberpsychology, Behavior and Social Networking, 17(10), 652-657.

Peterson, J. B. (1999). Maps of Meaning: The Architecture of Belief. Routledge.

Prinz, F., Schlange, T., \& Asadullah, K. (2011). Believe it or not: how much can we rely on published data on potential drug targets? Nature Reviews Drug Discovery, 10(712).

Ra, C. K., Cho, J., Stone, M. D., \& al., e. (2018). Association of Digital Media Use With Subsequent Symptoms of Attention-Deficit/Hyperactivity Disorder Among Adolescents. JAMA, 320(3), 255-263.

Rakic, P. (2009). Evolution of the neocortex: Perspective from developmental biology. Nature reviews. Neuroscience, 10(10), 724-735.

Richerson, P. J. (2006). Not by Genes Alone: How Culture Transformed Human Evolution. University of Chicago Press.

Rindermann, H., Flores-Mendoza, C., \& Woodley, M. A. (2012). Political orientations, intelligence and education. Intelligence, 40(2), 217-225.

Roach, M., \& Sauermann, H. (2017). The declining interest in an academic career. PLoS One, 12(9).

Rosen, D., Smith, S., Huston, H., \& Gonzalez, G. (2006). Empirical Study of Associations Between Symbols and Their Meanings: Evidence of Collective Unconscious (Archetypal) Memory. The Journal of analytical psychology, 36, 211-228.

Rosenberg, N. (1982). Inside the black box: technology and economics. Cambridge University Press.

Rury, J. L., \& Tamura, E. H. (2019). The Oxford Handbook of the History of Education. Oxford Universtiy Press.

Samuels, A. (1986). Jung and the Post-Jungians. Routledge.

Santa Monica College. (2017). 2017 College Employee Satisfaction Survey. Santa Monica College.

Schaffner, S., \& Sabeti, P. (2008). Evolutionary Adaptation in the Human Lineage. Nature Education, 1(1), 14.

Schwär, H., \& Moynihan, Q. (2020). Instagram and Facebook are intentionally conditioning you to treat your phone like a drug. Business Insider.

Seligman, D. (1992). A Question of Intelligence: The IQ Debate in America. Birch Lane Pr.

Siclari, F., Baird, B., Perogamvros, L., \& al., e. (2017). The neural correlates of dreaming. Nature Neuroscience, 20, 872-878.

Stiegler, B. (1998). Technics and Time, 1: The Fault of Epimetheus. Stanford University Press.

Tortora, G. J. (2008). Principles of Anatomy and Physiology. Wiley. 


\section{DESTRUKTIVNI UTICAJ POSTHUMANISTIČKE \\ SEMIOTIČKE IDEOLOGIJE NA AKADEMIJU KAO ARHETIPNI ENTITET}

Trut, L. N. (1999). Early Canid Domestication: The Farm-Fox Experiment: Foxes bred for tamability in a 40-year experiment exhibit remarkable transformations that suggest an interplay between behavioral genetics and development. American Scientist, 87(2), 160-169.

Trut, L., Oskina, I., \& Kharlamova, A. (2009). Animal evolution during domestication: the domesticated fox as a model. BioEssays, 31(3), 349360 .

Twenge, J. M., \& Campbell, W. K. (2010). The Narcissism Epidemic. Simon and Schuster.

Twenge, J. M., \& Foster, J. D. (2010). Birth Cohort Increases in Narcissistic Personality Traits Among American College Students, 1982-2009. Social Psychological and Personality Science, 1(1), 99-106.

Twenge, J. M., Twenge, J. M., Exline, J. J., \& Grubbs, J. B. (2016). Declines in American Adults' Religious Participation and Beliefs, 1972-2014. SAGE Open, 6(1).

Tylén, K., Fusaroli, R., Rojo, S., \& al., e. (2020). The evolution of early symbolic behavior in Homo sapiens. Proceedings of the National Academy of Sciences, 117(9), 4578-4584.

Ueda, M., Takeuchi, N., \& Kaneko, K. (2017). Stronger selection can slow down evolution driven by recombination on a smooth fitness landscape. PLOS ONE, 12(8).

Vater, A., Moritz, S., \& Roepke, S. (2018). Does a narcissism epidemic exist in modern western societies? Comparing narcissism and self-esteem in East and West Germany. PLoS One, 13(1).

Walters, S. (1994). Algorithms and archetypes: Evolutionary psychology and Carl Jung's theory of the collective unconscious. Journal of Social and Evolutionary Systems, 17(3), 287-306.

Wang, J., Veugelers, R., \& Stephan, P. (2017). Bias against novelty in science: A cautionary tale for users of bibliometric indicators. Research Policy, 46(8), 1416-1436.

Weeden, S., Cooke, B., \& Mcvey, M. (2013). Underage Children and Social Networking. Journal of Research on Technology in Education, 45(3), 249-262.

Western Kentucky University. (2008). Western Kentucky University Staff Satisfaction Survey 2008. Western Kentucky University.

Wilber, K. (1996). The Atman Project: A Transpersonal View of Human Development. Wheaton, IL: The Theosophical Publishing House. 
Williams, G. C. (2018). Adaptation and Natural Selection: A Critique of Some Current Evolutionary Thought. Princeton University Press.

Witherspoon, M., Maldonado, N., \& Lacey, C. H. (2010). Academic Dishonesty of Undergraduates: Methods of Cheating. Annual Meeting of the American Educational Research. Denver, Colorado.

Wunn, I. (2000). Beginning of Religion. Numen: International Review for the History of Religions, 47(4), 417-452.

Wurz, S. (2012). The Transition to Modern Behavior. Nature Education Knowledge, 3(10).

Wynn, T., \& Coolidge, F. L. (2011). The implications of the working memory model for the evolution of modern cognition. International Journal of Evolutionary Biology.

Žižek, S. (2019). The Sublime Object of Ideology. Verso. 


\title{
IGOR ŠEVO
}

University of Banja Luka, Faculty of Electrical Engineering, BiH

\section{THE DESTRUCTIVE INFLUENCE OF POSTHUMANIST SEMIOTIC IDEOLOGY ON THE ACADEMY AS AN ARCHETYPAL ENTITY}

\begin{abstract}
Aspects of human behavior usually ascribed to the modern age remained fundamentally inviolate during the past several hundred thousand years, but the globally accessible technology of the modern age creates a platform for the emergence of novel selection pressures on the human species, thereby allowing for modification of not only the genetic makeup of a human being, but its phenomenal experience. The globally accessible technology enables semiotic amplification and propagation of an implicit posthumanist ideology, threatening to alter the human being and its consciousness on a phenomenal level. In this paper, I derive an analytical argument that indicates an endangerment of the shared human phenomenal experience, exemplified by analyzing the endangerment of the academic ideal, under the premise of ethical and ontological relevance of phenomenal experiences.
\end{abstract}

Keywords: semiotic ideology, collective unconscious, posthumanism, information hazards, academy

Primljeno: 5.3.2021.

Prihvaćeno: 29.6.2021. 
